\title{
VERTICAL HOLINESS IN A LEVEL BUILDING DESIGN
}

\author{
I Made Sastra Wibawa*, I Wayan Redana, Putu Alit Suthanaya, \\ Ngakan Made Anom Wiryasa
}

Doctor of Engineering Science Program, Udayana University, Denpasar, Indonesia

*Corresponding Author e-mail: sastrawibawa@gmail.com

\begin{abstract}
The increasing number of residents demands the provision of more residential facilities and infrastructure. Limited land is an obstacle to do horizontal development, especially the use of green open land which will cause land conversion. There are restrictions on building height regulated by local regulations and with the existence of local wisdom, namely vertical sanctity that can be a challenge related to the idea of making high-storey buildings. When you want to enter the lower floors of a multistorey building, there is a feeling of doubt and lethargy because there are residents on the upper floor who stepped over. Vertical sanctity not only a challenge but can also be expected as an opportunity for acceptance of multi-storey buildings through a closer and correct understanding. This study aims to reveal the relationship between vertical sanctity and the design of high-storey buildings and formulate the height of vertical sanctity as an effort to implement it in design so that it can be accepted. This study uses a methodology to examine the problem with interviews with stakeholders and questionnaires in order to obtain a vertical sanctity relationship with the design of high-storey buildings. The data obtained were analyzed with descriptive statistics and logistic regression. The results of the study stated that there was indeed a link between vertical holiness and the design of multi-storey buildings, so the design should pay attention to this vertical holiness. This fact is proven by the acceptance of the hypothesis with significance level $\alpha=0.05$, where the results of data analysis show "significance $<\alpha$ " ie $0.036<0.05$, meaning that vertical holiness significantly influences building height. The conducted study also encourages the formulation of high vertical holiness to be set forth in legality/regulation so that it is easily understood and accepted by the public.
\end{abstract}

Keywords: Vertical sanctity, high-storey building, leteh/cemer.

Cite this Article: I Made Sastra Wibawa, I Wayan Redana, Putu Alit Suthanaya, Ngakan Made Anom Wiryasa, Vertical Holiness in a Level Building Design. International Journal of Civil Engineering and Technology, 11(2), 2020, pp. 192-202.

https://iaeme.com/Home/issue/IJCIET?Volume $=11 \&$ Issue $=2$ 


\section{INTRODUCTION}

Local genius as a valuable legacy from predecessors must always be maintained in the community so that it still exists even if it needs to be developed so that it has more value and meaning. Vertical holiness as a local genius has been steady and developed in Balinese society, so we hope it will not become a serious obstacle related to the construction of civil engineering infrastructure such as multi-storey buildings. Rejection of the construction of high-storey buildings or flats by some people because of vertical holiness is not well understood. Other community groups do not pay attention to this problem, so they accept the construction of multi-storey buildings or flats. This different opinion ultimately leads to pros and cons; therefore, the role of stakeholders is needed in finding solutions that can minimize or eliminate the difference.

Construction of flats or multi-storey buildings is an effort to be able to reduce land-use horizontally. According to Kamaruzzaman (2018), limited land and the economic crisis demanded the government's role in providing affordable housing [7]. As a result, the developments in various ways will require the provision of settlements so that it is often done by opening new land or using land that was not previously intended for settlements but eventually built buildings or houses. This can ultimately trigger land conversion or land use transfer. If this is not closely monitored or controlled by the authorities, this land-use change will be very detrimental when green open land is used as residential land. Building height regulation as stipulated in Bali Province Regulation No. 16 year 2009, which limits the maximum building height to fifteen meters is also feared as a trigger for the development of residential land horizontally.

The different opinion that often arises is when the operation of a multi-storey building, there are some people who do not want to go into the floor below because they have an assumption on the top floor that there are people who step over them. Those who are on the ground floor areas feel that they are being stepped on by those on the floor above, and there is a feeling of fatigue/flare because they are on the bottom floor. These conditions should be resolved or sought a way out so that land-use change can be suppressed, and those who feel lethargy when they enter the lower floors of high-storey buildings, they will no longer feel awkward and even feel relieved if they have to live on the lowest floor.

To solve these problems needed a good understanding of vertical holiness. An in-depth understanding of vertical sanctity is very necessary because this is local wisdom, so the inclusion of stakeholders is needed such as elders, sulinggih/pinandita or those who pursue this problem. The concept of the limits of the vertical purity found in some ancient scripts can be used as a reference. With the discovery of the concept of vertical sanctity limits, it is deemed necessary to conduct a deeper study so as to minimize the differences of opinions that occur.

Based on the background description of the problem above, the problem formulation can be proposed as follows: can the community accept or reject the concept of vertical holiness in a multi-storey construction? This study aims to address issues related to vertical holiness in relation to the design of multi-storey buildings such as: to know that vertical holiness is accepted or rejected by the community in multi-storey building design and alternative design efforts are undertaken so that the pros and cons are minimized.

\section{LITERATURE REVIEW}

\subsection{Values of Vertical Holiness in Spatial Spaces}

When doubts arise, awkward, lethargic when going into the basement of a multi-storey building, this is where the values of vertical holiness begin to be taken into account. In the 
beginning, when we talked about vertical holiness was a taboo, but lately, discussion about vertical holiness can be said something that is bold to say so that through discussion and often being talked about the community will have positive insights so that doubts no longer exist when entering to the lower floors of high-storey buildings. The understanding of vertical holiness height is not as high as the existing space, nor is it as far as the eye can see, but as stated in the sacred library in Bali (Budayoga (a), Without years; Lontar Purwaka Weda), (Budayoga (b), Without Years; Lontar Surya Sewana), (Tinglis, No Year; Lontar Surya Mandala) $[2,3,16]$. Further explained by the owner of the palm ejection that the limits of the vertical purity contained in the ejection have become a necessity in practicing it in daily life, especially in the implementation of religious ceremonial activities related to sor - singgih, contempt - main, and others. In Hinduism, especially in Bali, vertical holiness is always used as a guide in the implementation of religious ceremonies.

\subsection{Vertical Holiness according to Balinese Cultural Values}

Vertical holiness in the concept of life is an embodiment of cultural philosophy which is rooted in the religious philosophy of the cosmos imbued by Hinduism. The belief of the Hindu community in this matter is always trying to harmonize the relationship between psychology with the natural world of mortals through symbols, as a manifestation of the relationship between macro nature and the microcosmos. Basically, these two elements are different but are believed to have similarities and influence each other in a concept of $r w a$ bineda/dualistic. According to Puja (1978), the differences that exist are the human body as the microcosmos and the universe as a macro cosmos, but both are formed from the same elements [11]. Ardana (1982) states that humans as microcosmos are also referred to as bhuana alit, while the universe as macro cosmos is also called bhuana agung, these two forms must always maintain harmony to maintain harmony [1]. Pros and cons arising from the lack of understanding of vertical holiness should be carried out in-depth studies so that the harmony of the macro cosmos (bhuana agung) with the microcosmos (bhuana alit) is maintained. The next hope is that the construction of a multi-storey building will no longer be a debate and no group will feel disadvantaged.

\subsection{Lontar Purwaka Weda, Surya Sewana, and Lontar Surya Mandala}

In accordance with what is stated in the ejection, it turns out that vertical holiness has definite limits, as in the Lontar Purwaka Weda and Lontar Surya Sewana are twelve guli on the top of the fontanel. The distance of the twelve Guli is an area that must be preserved purity, while one Guli according to Asta Kosala-Kosali in the development concept in Bali is a distance/length of the second segment of the index finger (Saraswati, 2002) [13]. Finger size used is the finger of the head of the family or those who are considered the oldest or elder in a family. In general, the length of the two index fingers is an average of two and a half centimeters, thus twelve guli is equal to thirty centimeters. In another palm ejection, the Solar Mandala Lontar, it is found that the limit of purity is one cubit, while one cubit in the KosalaKosali Asta is the length of the arm from the tip of the elbow to the tip of the finger in a straight position. If the average length of an adult's arm is measured around 35 to $45 \mathrm{~cm}$, if the center is forty centimeters, the difference between one palm ejection is not too far away so that the logic is acceptable.

\subsection{Development of Multi-storey Buildings}

Sullivan and Arthur (2003), explained that building as a civil infrastructure is a fundamental physical need for organizing a structural system to ensure that the economy can function properly [15]. Floor elevation that is different from one another is a hallmark of a multi-storey building, which in its function some people do not want to go straight into the lower floor. 
This fact is often an obstacle when operating a multi-storey building and lead to pros and cons.

The Regional Government of Bali (2009), as stipulated in the Provincial Regulation of Bali Province Number 16 Year 2009 concerning Spatial Planning of Bali Province in 2009 to 2029 stipulates that the utilization of air space height above the earth's surface is limited to a maximum of fifteen meters, except public buildings and buildings specifically for safety and security purposes such as monitoring towers [10].

The construction of multi-storey buildings might raise the question of how the arrangement of green plants on the upper floors of the building is. This fact is a demand for the existence of thermal comfort, a cool atmosphere, and efforts to meet the needs of oxygen in the body. Research conducted by Medl et al. (2017) answer these questions by stating that to achieve thermal comfort in urban areas with high-rise buildings can be done with a vertical garden system attached to the walls of buildings [9]. With the presence of many green plants, it is expected to absorb the heat that occurs so that the heat pressure will be reduced, so the thermal comfort is not disturbed. This vertical garden will not take the land to the side because it is installed by sticking to walls or walls of buildings or fences, so as to save the land.

Research conducted by Feng (2011), by measuring the performance of residential sound insulation in Taiwan comparing field sound insulation with the standards used ISO 140-4 and 1407 [5]. The building understudy was a house with concrete floors, cement mortar, and tiles. The results of his study showed that there was a difference in the field sound insulation of 5 to $9 \mathrm{~dB}$ which indicated that the residential space was affected by lateral noise from the corridor. Therefore, the suggestion put forward was the need to increase the isolation of the fieldwork with the surface material for decorating the floor and ceiling of the house.

Similar research was conducted in Shah Alam, Selangor, Malaysia by Fairus et al. (2001), who conducted studies in several multi-storey buildings with different characters that have two opposite sides. One building has two sides that are exposed to the outside environment, and another building on both sides shares a wall with the house next to it (closed). The results of his study showed that closed buildings have greater pollution compared to open buildings [4]. Another researcher, Wan et al. (2011), in his experimental study simulated several methods on the passive environmental conditions of a multi-storey house architecture built in a line, where the weather/climate variable, the occupants were kept constant [17]. This simulation shows the results that the rooms in the home are lined up creating thermal discomfort eight times longer than the passive architecture each year. Suggestions proposed in this study are requiring additional environments such as landscape and natural ventilation settings. Room height regulation also has an important role related to the occurrence of free air circulation so that thermal comfort is achieved.

\section{METHODOLOGY}

\subsection{Study Location}

Badung Regency, Bali was chosen as the study location because this area has quite a lot of high-storey buildings such as Nusa Dua tourist complex, Unud Campus in Jimbaran, Kuta tourist destination, Badung Government Center, and several other places. The locations being built are also quite a lot such as the development of offices for Badung government, the development of tourist attractions in South Kuta, the development of the Benoa Sea Port, and many others. The future development of Badung Regency has many locations with high prospects for the construction of high-storey buildings such as the development of Uluwatu tourism objects, the development of Petang agro-tourism, the development of the Nusa Nua tourist settlement area, and others. 


\subsection{Data Sources}

Data needed to be analyzed is then obtained from several methods, locations and sources such as:

- Observation by making direct observations to several study objects and document and record all data obtained in the field.

- Conducting direct interviews with several respondents, especially those who are considered to understand the topic being studied (relevant stakeholders).

- Questionnaire, in the form of a questionnaire consisting of several questions that are answered directly by respondents in accordance with their understanding of the matter studied.

\subsection{Study Procedures/Steps}

Conducting observations and investigations as well as examining issues regarding vertical sanctity, approaching stakeholders who understand about vertical sanctity, to then be interviewed about their opinions on the topic to be studied. Conducting a literature study about vertical purity, especially regarding research or previous studies that have been conducted by other researchers.

Determining the variables that will be used in this study can be made the necessary research instruments, including the preparation of questionnaires that will be used to input data.

Circulation, filling out the questionnaire and conducting more intensive interviews with related parties so that the vertical purity data collected is needed for further analysis. Finally, conclusions are drawn from the studies conducted and complete set out in a research report.

\subsection{Research Variables}

The dependent variable in this study is people's acceptance of vertical sanctity. The attitude/acceptance of this community is based on research Kumar, et al, (2017) which states that accepting the reality that exists due to the development of various things very rapidly so that creative and innovative thinking arises [8]. The attitude of acceptance, in this case, is related to the application of vertical holiness in the design of multi-storey buildings, whether the community accepts or rejects the construction of multi-storey buildings with the role of vertical holiness in their designs. The dependent variable in this study is the dummy variable. Category 1 for people who receive vertical holiness in the construction of multi-storey buildings and 0 for those who don't.

The independent variables in this study are:

- Public perception of vertical sanctity, the public perception of vertical sanctity that causes doubts in determining the design of infrastructure / high rise buildings. The emergence of this variable is based on the results of research conducted by Rankavat, et al, (2016) which states that the perception that occurs in the community that the occurrence of congestion is due to the risk of pedestrians. So that it needs a high-rise building as a crossing infrastructure for pedestrians [12].

- Community experience in entering or using multi-storey buildings. This community experience is also thought to influence the attitude/acceptance of the community in designing infrastructure/high-storey buildings. This variable is supported by Medl, et al (2017) which states that the experience of exposure to uncomfortable thermal temperatures can be anticipated by creating vertical gardens in high rise buildings [9]. 


\subsection{Data Analysis}

The analysis conducted in this study are:

- The qualitative analysis method begins with the identification of vertical purity in spatial aspects, then is associated with its influence on the design of high rise buildings. Starting with a theoretical study in order to obtain a theoretical framework to be used as a guide in conducting interviews with Hindu experts/scholars.

- The data of vertical purity obtained from the palms and the results of the interviews were linked to the design of the multi-storey building, translated in the form of questionnaire questions which were then filled in by respondents. Initial testing was carried out validity and reliability tests on the questionnaire used. The statistical method used to test hypotheses is logistic regression (Ghozali, 2016) which states that this method is best used for research where the dependent variable is categorical [6].

\section{RESULTS AND DISCUSSION}

Vertical sanctity as local wisdom, in relation to the design of multi-storey buildings, should be examined in various ways, especially in terms of religion and culture. Supported by culture and belief in embracing one of the religions, local wisdom is certainly very thick with the basic life of a society. In Bali, culture and Hinduism are two things that have been integrated into the life of the community so both are often used as the basis of life in society. Vertical sanctity in relation to spatial planning is often taken into account in the layout of ceremonial layouts in religious ceremonies, building layout arrangements for both daily use and building layout when there are traditional ceremonies or religious ceremonies.

\subsection{Test Validity}

According to Sugiyono (2017), the validity test is needed because it is used to measure the validity of the questionnaire used and also shows the degree of accuracy between the data that actually occurs on the object with the data reported by the researcher [14]. The basis for decision making is whether or not the items in the questionnaire are valid if the total value of the Pearson Correlation for each item shows a value above 0.30 . The instrument can also be declared valid if the level of significance is less than 0.05 (Ghozali, 2016) [6].

Table 1. Validity Test Results

\begin{tabular}{llccc}
\hline Variable & \multicolumn{1}{c}{ Statement Item } & $\begin{array}{c}\text { Pearson } \\
\text { Correlation } \\
\text { Value }\end{array}$ & Sig. & $\begin{array}{c}\text { Infor- } \\
\text { mation }\end{array}$ \\
\hline Perception & $\begin{array}{l}\text { 1.Multi-storey buildings can overcome the } \\
\text { problem of slums. }\end{array}$ & 0,768 & 0,000 & Valid \\
& $\begin{array}{l}\text { 2.Building a horizontal building requires a } \\
\text { large area. }\end{array}$ & 0,758 & 0,000 & Valid \\
& $\begin{array}{l}\text { 3. The vertical sanctity limit above the crown is } \\
\text { 12 Guli. }\end{array}$ & 0,763 & 0,000 & Valid \\
& $\begin{array}{l}\text { 4. The vertical sanctity limit above the crown is } \\
\text { 1 Hasta. }\end{array}$ & 0,860 & 0,000 & Valid \\
\hline Experience & $\begin{array}{l}\text { 1. When entering a multi-storey building there } \\
\text { is a sense of fatigue. }\end{array}$ & 0,814 & 0,000 & Valid \\
& $\begin{array}{l}\text { 2. Frequently in and out of high rise buildings } \\
\text { so that they understand about vertical purity. } \\
\text { 3. When there are religious activities, religious } \\
\text { symbols may not enter multistory buildings. } \\
\text { 4. When entering the lower floor of a multi- } \\
\text { story building as if the head will hit. }\end{array}$ & $0,0,749$ & 0,000 & Valid \\
\hline
\end{tabular}


Based on the test results in table 1, the Pearson Correlation values of all question items are greater than 0.3 and the significance of all question items is below 0.05 . This shows that the items in the question to measure the perception variable and the experience variable are valid.

\subsection{Reliability Test}

Reliability test is a tool to measure a questionnaire which is an indicator of a variable or constructs. Relevant data is reliable data because it can be trusted, the data tends to be valid (Sugiyono, 2017) [14]. The research instrument is said to be reliable if it has a Cronbach's Alpha value of greater than 0.70 . Based on the results of the reliability test as shown in Table 2 , it can be concluded that all variables have a Cronbach's Alpha value greater than 0.70 . Thus means the instrument in this study is reliable.

Table 2 Reliability Test Results

\begin{tabular}{ccl}
\hline Variabel & cronbach's alpha value & Description \\
\hline Perception & 0,789 & Reliabel \\
Experience & 0,776 & Reliabel \\
\hline
\end{tabular}

\subsection{Logistic Regression Analysis Test}

\subsubsection{Assess the Feasibility of the Regression Model}

The feasibility of the regression model was assessed using the Hosmer and Lemeshow's Goodness of Fit Test. Hosmer and Lemeshow's Goodness of Fit Test tests the null hypothesis that empirical data matches or matches the model (there is no difference between the model and the data so the model can be said to be fit). If the statistical value of Hosmer and Lemeshow's Goodness of Fit Test is equal to or less than 0.05 , it means that there is a significant difference between the model and its observation value so that the Goodness of Fit model is not good because the model cannot predict the value of the observation. Conversely, if the statistical value of Hosmer and Lemeshow's Goodness of Fit Test is greater than 0.05, then the null hypothesis cannot be rejected and means that the model is able to predict its observational value or the model can be said to be acceptable because it matches the observational data (Ghozali, 2016) [6].

Based on the analysis results as in Table 3, the significance value of Hosmer and Lemeshow's Goodness of Fit Test was obtained by 0.334 which is greater than 0.05 . This shows that the model is able to predict the value of its observations or it can be said the model is acceptable because it matches the observational data.

Table 3. Hosmer and Lemeshow's Test Results

\begin{tabular}{|l|r|r|r|}
\hline Step & Chi-square & df & Sig. \\
\hline 1 & 2.193 & 2 & .334 \\
\hline
\end{tabular}

\subsubsection{Assess the Entire Model}

The overall fit model is a statistical test to determine whether all independent variables in logistic regression simultaneously influence the independent variables (Ghozali, 2016) [6]. Testing is done by comparing the value of -2 Log-Likelihood (-2LL) at the beginning (Block Number $=0$ ) with the value of -2 Log-Likelihood $(-2 L L)$ at the beginning (Block Number $=$ 1). The reduction in value between the initial $2 \mathrm{LL}$ and 2 final LL indicates that the model is hypothesized fit with the data. 
Based on the analysis results as shown in Table 4, the value of -2 Log-Likelihood ($2 \mathrm{LL}$ ) at the beginning (Block Number $=0$ ) is 39.442 which is greater than the value of -2 Log-Likelihood (-2LL) at -2 Log-Likelihood (-2LL) ) at the beginning (Block Number = 1) which is 22,082 . This means that the hypothesized model is fitted with the data.

Table 4 -2 Log Likelihood Values (-2LL)

\begin{tabular}{cc}
\hline -2 Log Likelihood & Score \\
\hline Block Number $=0$ & 39.429 \\
Block Number $=1$ & 22.082 \\
\hline
\end{tabular}

\subsubsection{Coefficient of Determination}

The coefficient of determination (R2) essentially measures how far the model's ability to explain variations in the dependent variable. The coefficient of determination is between zero and one. A small R2 value means that the ability of the independent variables to explain the variation of the dependent variable is very limited. A value close to one means that the independent variables provide almost all the information needed to predict the dependent variable (Ghozali, 2016) [6]. The magnitude of the coefficient of determination in the logistic regression model is indicated by the value of Nagelkerke R Square. Nagelkerke R Square value indicates the variability of the dependent variable that can be explained by the variability of the independent variable.

Based on the results of the analysis as in Table 5, the Nagelkerke R Square value of 0.600 was obtained. This means that 60 percent of the variation of the variable community acceptance of the construction of multi-story buildings in Badung is able to be explained by people's perceptions of vertical sanctity and the experience of people passing through multistorey buildings. The remaining 40 percent is explained by other factors outside the research model.

Table 5 Nagelkerke R Square Values

\begin{tabular}{|l|r|r|r|}
\hline \multicolumn{1}{|c}{ Model Summary } \\
Step & $\begin{array}{c}-2 \text { Log } \\
\text { likelihood }\end{array}$ & $\begin{array}{c}\text { Cox \& Snell } \\
\text { R Square }\end{array}$ & $\begin{array}{c}\text { Nagelkerke } \\
\text { R Square }\end{array}$ \\
\hline 1 & $22.082^{\mathrm{a}}$ & .439 & .600 \\
\hline
\end{tabular}

a. Estimation terminated at iteration number 6 because parameter estimates changed by less than .001 .

\subsubsection{Multicollinearity Test}

Multicollinearity test aims to test whether the regression model found a correlation between independent variables (independent). A good regression model should not occur the correlation between independent variables. Multicollinearity testing in logistic regression uses a correlation matrix between independent variables. If the correlation coefficient between independent variables is smaller than 0.8 , it means that there are no symptoms of serious multicollinearity between these independent variables (Ghozali, 2016) [6].

Based on the values in the correlation matrix as in Table 6 , it can be explained that the correlation of all independent variables does not exceed 0.8, this means that in the research model there is no correlation between the independent variables or the model is free from multicollinearity symptoms. 
Table 6 Correlation Matrix Values

\begin{tabular}{|ll|r|r|r|}
\hline & & Constant & Persepsi & Pengalaman \\
\hline Step & Constant & 1.000 & -.781 & -.720 \\
1 & Persepsi & -.781 & 1.000 & .462 \\
& Pengalaman & -.720 & .462 & 1.000 \\
\hline
\end{tabular}

\subsubsection{Logistic Regression Model}

The logistic regression model that was formed produced a regression coefficient and significance. The regression coefficient of each of the variables tested shows the form of the relationship between the variables. Hypothesis testing is done by comparing the significance value with the error level $(\alpha)$ if significance $<\alpha$, it can be said that the independent variable has a significant effect on the dependent variable.

In this study, it was tested by looking at the effect of changing people's perceptions about vertical sanctity and community experience of entering a multi-storey building on community acceptance of the construction of a multi-storey building in Badung. Based on the results of the logistic regression analysis as in Table 7, the logistic regression model in this study is:

Ln $($ Reception / 1-Reception $)=-2.361+2.626$ Perception +3.111 Experience

Information

Reception : community acceptance of the construction of multi-storey buildings

Perception : people's perception of vertical purity

Experience : community experience in entering multi-storey buildings

Table 7 Results of Logistic Regression

\begin{tabular}{|c|c|c|c|c|c|c|c|}
\hline \multicolumn{8}{|c|}{ Variables in the Equation } \\
\hline & & $\mathrm{B}$ & S.E. & Wald & $\mathrm{df}$ & Sig. & $\operatorname{Exp}(B)$ \\
\hline \multirow{3}{*}{$\begin{array}{l}\text { Step } \\
1\end{array}$} & Persepsi & 2.626 & 1.208 & 4.724 & 1 & .030 & 13.823 \\
\hline & Pengalaman & 3.111 & 1.221 & 6.488 & 1 & .011 & 22.442 \\
\hline & Constant & -2.361 & 1.126 & 4.398 & 1 & .036 & .094 \\
\hline
\end{tabular}

a. Variable(s) entered on step 1: Persepsi, Pengalaman.

From the description of people's perceptions and experience of entering a multistory building that there is acceptance of the concept of vertical purity in the construction of this multistory building in accordance with the results of the analysis which shows a significance smaller than alpha $(\alpha)$. Furthermore, the values of vertical purity should be included in the design of multi-story building construction. The main thing to note is to design the height of the space between one floor to another in order to add the height of vertical purity to the vertical distance between the first floor and the floor above and so on. With such a design, there is no longer any sense of excitement/fatigue so there is no awkward feeling in entering the multi-storey building.

In vertical holiness there is an element of feeling in it, therefore if the feeling does not want to enter mesulub into a high-rise building due to a sense of flare/lethargy, then there should not be coercion. To overcome this, the stairs are made outside the building, so that when going up to the top room no one stepped over so that there is no longer feeling tired/cemer. 


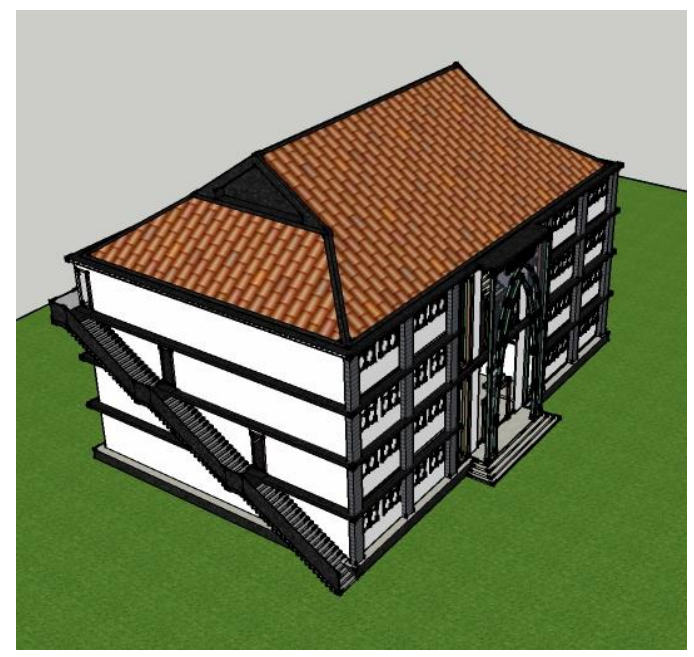

Figure 1. Storied building with outside staircase design.

For buildings that are used for the public such as halls, offices, etc., building designs can also be made by installing elevators outside the building so that when you want to go up to the fourth floor, you can directly pass the elevator without anyone stepping over so that you avoid the feeling leteh/cemer, like the following picture:

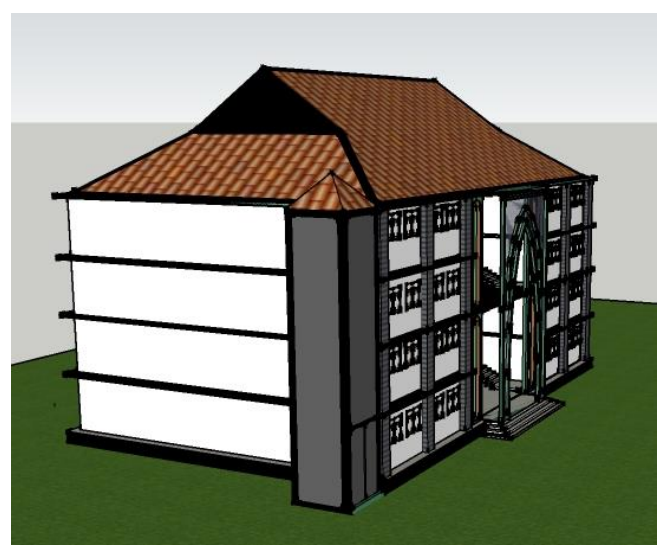

Figure 2. Fourth-floor building with elevator design outside.

\section{CONCLUSIONS AND SUGGESTIONS}

\subsection{Conclusions}

Based on the results of data analysis and discussion conducted, it can be concluded that the variable community perception of vertical sanctity and community experience through in multi-storey buildings has a positive effect on community acceptance of multi-storey building construction in Badung. This is evident from the results of the analysis test significance $=$ 0.036 smaller than $\alpha=0.05$. With this positive influence, the answer to the existing problem is that the community accepts the concept of vertical purity in the construction of multi-storey buildings. Therefore the construction of multi-storey buildings should consider the values of vertical purity in the design. Because vertical purity is related to feelings, and what if there is still a feeling of the block associated with leteh/cemer when going into the basement of a multi-storey building, alternative designs are still needed such as making stairs outside the building and installing elevators on the outside of the building. 


\subsection{Limitations and Suggestions}

This research does not consider events and other things that have consequences for the acceptance of the concept of a multi-storey building, for example, a person's profession in society as a pinandita/sulinggih, special or general building functions, or other problems that are likely to affect the acceptance or rejection of a multi-storey building. In the next research, it is expected to consider these variables. This study shows that vertical holiness has a positive effect on high rise buildings, therefore it can be suggested that if you want to build high rise buildings it should include the values of vertical holiness in its design/plan. Surely it would be better if this could be contained in the legality of the height of the building so that there are rules that are used as a reference to move.

\section{REFERENCES}

[1] Ardana, 1982, Agama Hindu dan Lingkungan Hidup, Denpasar, Proyek Seminar Kesatuan Tafsir Terhadap Aspek-aspek Agama Hindu.

[2] Budayoga (a), Tanpa Tahun, Lontar Purwaka Weda, Milik dari Drs. I.B. Gede Budayoga, M.Si ; Grya Basang Tamiang, Kapal, Mengwi, Badung, Bali.

[3] Budayoga (b), Tanpa Tahun, Lontar Surya Sewana, Milik dari Drs. I.B. Gede Budayoga, M.Si ; Grya Basang Tamiang, Kapal, Mengwi, Badung, Bali.

[4] Fairus. M.D, dkk, 2011, Teracced Residential Housing Indoor and Outdoor Air Quality in Shyah Alam, Malaysia, International Symposium \& Exhibition in Sustainable Energy \& Environmental 1-3 Juni 2011, Melaka, Malaysia.

[5] Feng. C.H, 2011, Measurenment and Estimation on Sound Insulation Performance of the Walls and Floor In Thaiwan Dwelling Housing, IEEE 978-1-61284-7740/11/\$26.00@2011

[6] Ghozali, 2016, Aplikasi Analisis Multivariate dengan Program SPSS, Semarang, Badan Penerbit Universitas Diponegoro.

[7] Kamaruzzaman, dkk, 2018, Residents' Satisfaction Towards the Indoor Environmental Quality of Re-engineered Affordable Housing Scheme in Malaysia, International Journal of Technology. Volume 9(3), pp.501-512

[8] Kumar, dkk, 2017, Does Connectivity Index of Trasport Network Have Impact On Delay For Driver, Science Direct Transportation Research Procedia 25 (2017) 4988-5002.

[9] Medl, dkk, 2017, Vertical Greening System - A Review on Recent Technologies and Research Advancement, Building and Environment.

[10] Pemda Prov. Bali, 2009, Perda Provinsi bali No. 16 Tahun 2009 tentang : Rencana Tata Ruang Wilayah Provinsi bali Tahun 2009 - 2029, Ka. Biro Hukum \& Ham Provinsi bali, Denpasar.

[11] Puja, 1978, Pelaksanaan P4 Bagi Umat Hindu Dharma, Jakarta, Dirjen Bimas Hindu dan Budha, Departemen Agama.

[12] Rankavat, dkk, 2016, Pedestrians risk perception of traffic crash and built environment features-Delhi, India, Safety Science 87 (2016) 1-7

[13] Saraswati. AAA.O, 2002, Pamesuan Edisi ke-2, Cetakan ke-2, Jimbaran-Bali, Penerbit Universitas Udayana.

[14] Sugiyono, 2017. Statistika Untuk Penelitian (Cet 2000), Badung, CV. Alfa Beta.

[15] Sullivan dan Arthur, 2003, Economics: Principles in Action, Upper Saddle River, New Jersey 07458: Pearson Prentice Hall. (474), ISBN 0-13-063085-3.

[16] Tinglis. K, Tanpa Tahun, Lontar Swamandala, Milik dari Jro mangku Ketut Tinglis ; Pemangku Gede Pura Desa, Desa Adat Abianbase, Mengwi, Badung.

[17] Wan. R.M.Z, dkk, 2011, Indoor Environmental Conditions in Passive Architecture Terracede House, International Symposium \& Exhibition in Sustainable Energy \& Environmental 1-3 Juni 2011, Melaka, Malaysia. 